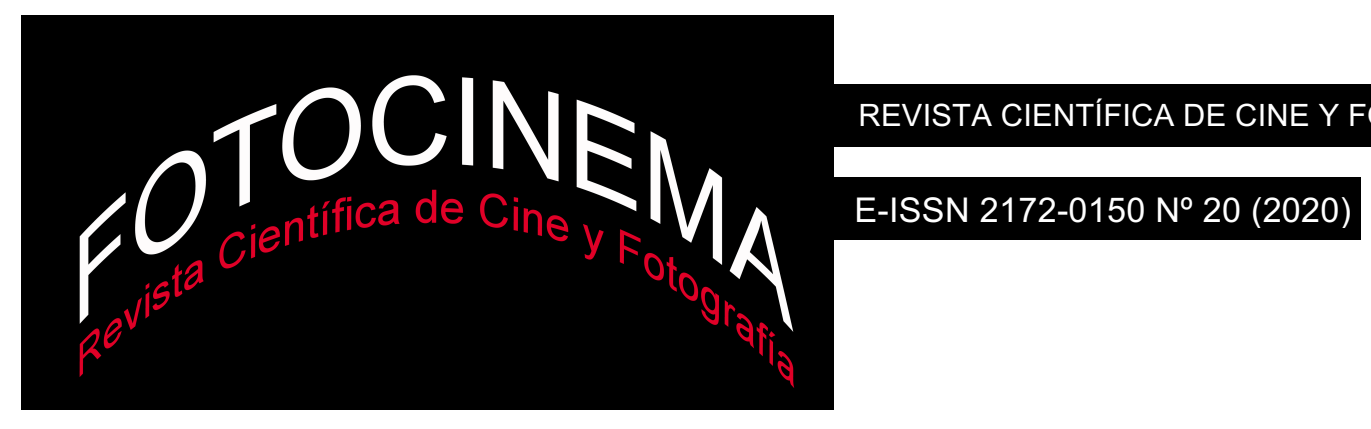

\title{
Poesía y fotografía. Defensa de la mirada constructora: un diálogo intermedial de Alberto García-Alix y Jenaro Talens
}

\author{
Poetry \& photography. A defense of the constructing view: an \\ intermedial dialogue between Alberto García-Alix \& Jenaro Talens
}

\author{
Concha Gómez \\ Universidad Carlos III, España \\ cogomezg@hum.uc3m.es
}

Domingo Sánchez-Mesa

Universidad de Granada, España

\section{Resumen}

dsanchez@ugr.es

En este artículo se lleva a cabo un ensayo de análisis comparatista entre la fotografía de Alberto García-Alix y la poesía de Jenaro Talens a propósito de la colaboración de ambos autores en el libro Lo que los ojos tienen que decir (Cátedra, 2014). El trabajo se fundamenta metodológicamente en una teoría radical de la intermedialidad y en los conceptos de imagentexto (WJT Mitchell 1994, 2019) y de iconotexto, término con el que el mismo Talens designa una serie de libros en los que su poesía ha dialogado en el tiempo con la imagen visual. A partir de una serie de categorías poéticas comunes (la articulación discursiva del sujeto, el deseo y la mirada constructora como fuerzas creadoras y la imagen poética como espacio común a fotografía y palabra poética) y de una serie de técnicas fotográficas que son simuladas y adaptadas por el poeta (encuadre, fuera de campo, profundidad de campo, exposición a la luz) este libro ofrece un caso extraordinario de resistencia a la estética realista, apostando por una concepción fuertemente material y espacial, abierta al misterio y comprometida en la deconstrucción ${ }^{1}$ de toda posible autobiografía o autorretrato en sentido referencial estrecho.

\section{Abstract}

This article provides the reader with a comparatist analysis of the dialogic bonds between the photographic work of Alberto García-Alix and the poetry of Jenaro Talens, specifically on their collaboration in the book Lo que los ojos tienen que decir (Cátedra, 2014). Its methodology is grounded in a radical understanding of intermediality and the concepts of imagentext (WJT Mitchell 1994, 2019) and iconotext, the latter being coined by Talens himself to designate a series of his books where the poetic word mingles and interacts with the visual image. Our research identifies a series of poetic (theoretical) common categories, such as the discursive configuration of subjectivity, desire (both in a psychoanalytical and a comparatist perspective) and constructing view (mirada constructora) as creative forces in this collaboration, together with some photographic techniques that the poet imports and adapts to its language (framing, off camera, depth of field, light exposure). As a whole, this book comes out to be an extraordinary case of resistance to the aesthetical dominance of realism, choosing to adopt a shared strong materialist and space stance, open to poetic mistery and compromised with the deconstruction of any possible autobiography or self-portrait in the narrow sense of self and referential coincidence.

Palabras clave: intermedialidad, imagentexto, poesía, fotografía, iconotexto, autobiografía, García-Alix, Talens.

Keywords: intermediality, imagetext, poetry, photography, iconotext, autobiography, GarcíaAlix, Talens.

$1 \mathrm{Si}$ bien la traducción más correcta del término francés déconstruction en español es desconstrucción, nosotros emplearemos el término deconstrucción, más extendido en la bibliografía derridiana en nuestra lengua. 


\section{Introducción}

Decía William J.T. Mitchell, uno de los autores fundamentales para los estudios visuales y de la intermedialidad: "there are no visual media", subrayando así de forma provocadora el principio diferencial o dialógico enunciado igualmente por él de que no hay medios puros ("all media are mixed media") dado que "the very notion of media and of mediation already entails some mixture of sensory, perceptual and semiotic elements" (Mitchell, 2005, p.399)². Este principio teórico, que hemos explorado en trabajos anteriores a propósito, por ejemplo, del caso de la adaptación fílmica de hechos reales, con el periodismo como discurso intermedio (Gómez/Sánchez-Mesa, 2011), se encuentra en la base de una concepción de los estudios comparatistas donde la constatación de que cualquier medio se encuentra en relación permanente y nace en contacto con otros medios, no es óbice para seguir trabajando con un concepto más complejo de especificidad mediática. En virtud del entendimiento de todo medio, al modo de Raymond Williams, como "práctica social material", se puede y debe incluir no solo tipos de signos y tecnologías de soporte, sino prácticas y hábitos sociales en torno al medio en cuestión, instituciones y mercados. De este modo, no solo la literatura deja de limitarse a su componente lingüístico verbal, sino que también la fotografía deviene un tipo de discurso complejo en el que tanto lo narrativo como lo poético funcionan sobre sus propias bases semióticotécnicas. Esta perspectiva teórico comparatista nos lleva en esta ocasión a explorar la relación intermedial entre fotografía y poesía en la obra de dos autores emblemáticos de las últimas décadas de la práctica de ambas artes en España, como son Jenaro Talens (Tarifa, 1946) y Alberto García-Alix (León, 1956). Ambos son coautores de un libro, objeto central de nuestro interés, que consideramos extraordinario en este terreno híbrido de la intermedialidad, Lo que los ojos tienen que decir (Cátedra, 2014).

\footnotetext{
2 "No hay medios visuales" [...] "todos los medios son medios mixtos" [...] "la noción misma de medio y de mediación ya conlleva algún tipo de mezcla de elementos sensoriales, perceptivos y semióticos" (la trad. es de los autores).
} 
El propio William J.T. Mitchell nos enseñó que las formas de coordinación de palabra e imagen, o imagentexto, siempre son sintomáticas de una relación de poder determinada (Mitchell, 1994), siendo frecuente la posición de superioridad de la primera respecto de la segunda, como síntoma de un logocentrismo que, a pesar del imperio de la imagen en la era digital y de la postfotografía ${ }^{3}$, sigue dominando en no pocos medios de comunicación contemporáneos (prensa escrita y online, televisión, ensayos, etc.). Por eso, si bien el pensamiento de Jenaro Talens, un teórico muy reconocido e influyente en la academia española e internacional, será ineludiblemente troncal en nuestra aproximación a esta relación y a su plasmación en el libro objeto de nuestra atención, tenemos que reconocer que García-Alix no lo es (teórico), lo cual no quiere decir que no haya vertido su concepción y autopercepción de la fotografía de forma verbal en distintas ocasiones y, por tanto, comenzaremos nuestro propio discurso, deconstruyendo ese impulso logocéntrico de la teoría para dar voz al pensamiento del fotógrafo en primera instancia y luego ver cómo el poeta articula y organiza dicha colaboración 4 .

\subsection{Alberto García Alix: la mirada del Cíclope}

Los encuentros, en muchas ocasiones, no son casuales y no es extraño en este caso que dos personas con mundos o trayectorias "aparentemente" tan dispares hayan llegado a un espacio común con la publicación de esta obra solo posible por la mutua admiración hacia el trabajo del otro. "Imagen y palabra, nada más allá”, escribía hace años el fotógrafo (García-Alix, 2011)5.

Con anterioridad a Lo que los ojos tienen que decir Alberto García-Alix y Jenaro Talens (AGA) y (JT) ${ }^{6}$ ya se habían encontrado en la edición de $E l$

3 El propio Mitchell acuñó el término en The Reconfigured Eye. Visual Truth in the Postphotographic Era. MIT Press, 1992.

4 No hay que olvidar que la colaboración entre los artistas siempre fue otra línea de trabajo y análisis comparatista clásico (vid. Kibedi-Varga, 2000)

5 Es importante recordar, de todos modos, que Talens escribió sobre la autorreflexividad en los catálogos de dos exposiciones de García-Alix, ambas de 2008, Far from Home (Paris, Galerie Kamel Mennour) y la retrospectiva De donde no se vuelve (Madrid, Museo Reina Sofía).

${ }^{6}$ A partir de este punto se podrá citar a los autores objeto de este estudio con sus iniciales: Alberto García-Alix (AGA) y Jenaro Talens (JT) 
truco preferido de Satán (Benjamin, 2012), selección de fragmentos de $E l$ libro de los pasajes, con fotografías de García-Alix y traducido por Vicente Forés y el propio Jenaro Talens. Así pues, en este nuevo proyecto se dan cita dos trayectorias que convergen tras décadas de exploración en disciplinas artísticas distintas pero cuyos horizontes se observaron con catalejos compartidos. García-Alix es uno de los fotógrafos más (auto)reflexivos de la España contemporánea, sin duda alguna porque la literatura y la historia son claves en su trabajo, porque su interés por la prosa radical de Céline o por los personajes que pueblan el mundo de Conrad han atravesado inevitablemente su mirada. Quizá por esto, el fotógrafo nacido en León, inequívoco representante del movimiento underground conocido como la Movida, ha ido creando en artículos, libros y finalmente también en otros formatos audiovisuales, un diálogo muy fructífero entre dos conceptos que son el centro de su creación artística: "la palabra es posesiva, absorbente; la imagen, propietaria, inapelable. La Imagen congela el tiempo, la palabra lo desarrolla" (García-Alix, 2011).

Ese pensamiento intuitivamente intermedial al que nos referimos se registra en no pocas sentencias: "Nada hay más creíble que la imagen. Pero nada que no haga visible la palabra", escribía en El Paraíso de los creyentes, para dejar clara la creencia de que "en la palabra se refugia nuestra fe" y que "con palabras todo es visible" porque "solo ellas acercan nuestros ojos al infinito" (2011). Ese carácter autorreflexivo ha acompañado siempre a García-Alix, incluso desde sus primeras exposiciones individuales y colectivas si bien, como dice Miquel Barceló, "Alberto ha cambiado muchas veces de piel"7. Desde las primeras imágenes, desde los primeros pasos concretados en su primera muestra individual, el autor ha estado en cada una de sus obras, incluso en las más naturalistas. "La fotografía es un poderoso médium. Nos lleva al otro lado de la vida”, escribía en el prólogo de Dónde no se vuelve y es que su manera de mirar, su forma de ver la ciudad de los años ochenta retrataba no sólo a personajes claves de la noche madrileña o a seres

7 Testimonio recogido en el documental Alberto García-Alix. La línea de sombra, de Miguel Ángel Delgado y Nicolás Combarro (2018). 
anónimos representantes de esas nuevas identidades que vomitaba una nueva sociedad, sino que invariablemente lo que mostraba era su propia forma de ser. "Decido cómo y dónde mirar. Aún más, he desarrollado una mirada frontal, una mirada de púgil, parapetado tras ella me convierto en un cíclope con un único ojo anhelante", escribía en el prólogo de Llorando a aquella que creyó amarme (2008, p.85).

No creemos que Alberto García-Alix pueda o deba considerarse un cronista de una época determinada de este país, pero sí que ha sido un testigo visual de esa España en transición que, junto a otros fotógrafos de la Movida “parecen estar más interesados en observar y retratar, desde diferentes ángulos, a los sujetos que una nueva sociedad (posmoderna) está haciendo emerger y a aquellos otros que la sociedad está convirtiendo en ídolos mediáticos, y los construyen como sujetos del presente, en la calle y como figuras de la escena cultural, en sus pedestales" (Moreiras, 2010, p. 137).

Roland Barthes afirmó que "la foto no es una "copia" de lo real, sino una emanación "de lo real en el pasado: una magia, no un arte” (1982, p. 154). En dicho sentido se ha escrito en numerosas ocasiones que García-Alix no retrata la realidad, sino que la escenifica (como otros autores de su generación), atendiendo a su espectáculo, mostrando al espectador escenas premeditadamente construidas y con una clara intencionalidad en la mirada. Sus imágenes son "metáforas de mi visión del mundo", constatando también que son la "odisea de su catástrofe", escribía en los inicios del siglo XXI (2008, p. 85).

Esa mirada de (re)conocimiento, la (auto)reflexión o el (auto)retrato, constante en la trayectoria de un fotógrafo que siempre se consideró aprendiz de poeta, ha ido trazando inevitablemente el camino hacia territorios cada vez más introspectivos y abstractos. "Para mí, la fotografía es fundamentalmente una forma de hacer poesía”, confesaba García-Alix en un texto que analizaba sus primeros años (1977-1998). Y más adelante afirmaba: "El problema no es que las fotos sean buenas o malas, sino reconocerte, encontrar en ellas una mirada intensa. No es el resultado lo que cuenta, sino 
el trance, el momento que vives cuando estás con la cámara" (2008, p. 100). Quizá por esto, todas sus fotografías, desde finales de los setenta hasta los comienzos de los años 2000, son un intento de aprehender esbozos de la realidad y de reflexionar en sus textos sobre su principal pasión, la fotografía, pero también de la muerte, los amigos, las drogas, porque toda su obra plantea un pulso con la posibilidad de lo autobiográfico que estamos cuestionando aquí:

No soy capaz de inventar. No tengo nada que contar que no sea yo mismo. Necesito estar de cuerpo presente, fotografiar mi entorno inmediato, lo que puedo tocar, lo que encuentro delante. Si no hay encuentro no hay nada. La magia de la vida es el encuentro. Una de las grandes lecciones que debe aprender un fotógrafo es la de prescindir de todo aquello que distrae la atención (García-Alix, 2008, p. 96).

La vida, su propia conciencia del hecho fotográfico y la trayectoria ya caminada le llevan a cambiar su forma de enfrentarse a las imágenes. En el tránsito de siglo, AGA se hace más introspectivo, no mira tanto al exterior como al interior de sí mismo y sus imágenes abandonan los brochazos de realidad para hacerse más líricas, más abstractas y difusas, de ahí que dialoguen a la perfección con los poemas de JT: "si ayer fotografiaba silencios hoy fotografío mi propia voz”, escribía en el guion cinematográfico De donde no se vuelve.

\subsection{La mirada constructora: El iconotexto de Jenaro Talens y exploraciones en el espacio tercero}

Hay tres conceptos que identificamos como comunes a la poética de los dos autores que nos ocupan aquí: a) la articulación entre sujeto y discurso; b) el deseo "del otro", tanto en términos psicoanalíticos de acceso a "lo real", como deseo del otro arte o medio; c) la mirada "constructora" o el "espacio" del iconotexto como encrucijada con el lector/espectador en la que surge el sentido. Se entiende aquí también la mirada como la configuración de un punto de vista. 
Reflexionando sobre la aparentemente generalizada derrota de la teoría en el ámbito académico norteamericano, Terry Eagleton certificaba en su último libro, The Event of Literature, el desplazamiento en el dominio de la teoría literaria desde "el discurso" hacia "la cultura" (2013, p. 11). En este contexto de crisis, el proyecto poético y teórico de Jenaro Talens, sostenido a lo largo de más de cuatro décadas, se presenta como más relevante aún si cabe. Así se percibía ya en la colección de textos teóricos tal vez más representativa de su obra ensayística, El sujeto vacío. Cultura y poesía en territorio Babel (Talens, 2000), un título que señala la problematización del concepto de sujeto como una de las claves de bóveda de su pensamiento teórico-literario. Talens siempre ha subrayado que es esta inquietud y esta pregunta por el sujeto la que le lleva al cine (y no a la inversa) y que empezó a estudiar cine cuando se dio cuenta que en el dominio audiovisual era menos complejo abordar el desmontaje de cuestiones como la identidad, la subjetividad o el concepto de autoría (Talens 2002e, p. 188).

Es importante poner de manifiesto, como hace también Juan Carlos Fernández Serrato (2015, p. 37), que en la poesía de Talens el deseo es un motor de la creación poética, una fuerza constitutiva del dispositivo lingüístico del cuerpo y de la experiencia vital en cuanto discurso que se encuentra al margen de cualquier autobiografismo confesional. El deseo, por otro lado, es objeto de una apelación bastante común también en la tradición comparatista del "ut pictura poesis" o de las artes hermanas (palabra e imagen), donde cada una de ellas anhela y desea "hacer" aquello para lo que la otra estaría especialmente dotada. Se cruzan así el deseo de la poesía por la música, la pintura $\mathrm{y}$, sobre todo en el caso de Talens, por el cine $\mathrm{y}$, consecuentemente, por la fotografía, con el deseo por la palabra en el caso de García-Alix, como hemos visto más arriba.

Otro factor, que es cualidad del sensorium humano pero sobre todo una capacidad individual entrenada precisamente en la práctica de la intermedialidad, es la "Mirada, entendida como estrategia discursiva para reivindicar la lectura como (co)creación de sentido" (Fernández Serrato, 2015, p. 74). La inclinación hacia lo visual, que es una marca generacional en 
la poesía española de los años 70, parece proyectarse en dos vías: a) a través del montaje y la presencia de la imagen animada, y b) en el diálogo con la imagen fija y en colaboración con artistas plásticos. Nosotros vamos a ocuparnos en este texto de la segunda de estas vías ${ }^{8}$. En esta ocasión, y a propósito de la relación intermedial de fotografía y poesía en Lo que los ojos tienen que decir (García Alix / Talens, 2014), el ojo de la cámara es como un tercer ojo al que está sometido el espectador, un ojo-guía que, entre otras cosas, podría relacionarse con la métrica poética.

En cualquier caso, el procedimiento creativo básico de su escritura es lo que se llama "mirada constructora", que tendrían en común poesía y fotografía. Lo que importa no es "lo que hay" sino "lo que construimos al mirar". No se trata de "imponer significados" sino de desplegar propuestas o posibilidades de sentido. De este modo Talens establece una conexión entre saber, es decir, la construcción de una posición subjetiva, y mirada, para establecer un principio que, por otra parte, consideramos central para la cultura digital en la llamada era de la información o sociedad red (Castells, 1998): "uno ve lo que está preparado discursivamente para ver, no lo que está delante del ojo" (Talens, 2002c, p. 191).

A la hora de acercarse a cualquier texto, Talens siempre ha enunciado la pregunta ¿quién y desde dónde mira? El recurso al punto de vista en el a menudo citado prólogo de Cenizas del sentido nos ayudará a entender mejor la importancia de este recurso: "Aunque nada de lo que he escrito puede desvincularse de una vivencia concreta, nunca he hablado de mí, pero siempre lo hice desde el único lugar del que me es imposible sustraerme, esto es, desde mí. Quiero decir que lo mío, si así hay que llamarlo, sería el punto de vista, nunca la anécdota argumental; el tono, no la melodía” (Talens 1989, p. 8). No es casualidad, como veíamos más arriba, que este sea uno de los conceptos que engarza su poética con la de AGA ("Decido cómo y dónde mirar...”, vid. supra). Este recurso está inextricablemente vinculado a las

\footnotetext{
8 De la primera ya nos ocupamos en un trabajo anterior sobre la presencia o huella del cine en su poesía dentro del conjunto de relaciones intermediales en su poesía (Sánchez-Mesa, 2007).
} 
técnicas del encuadre y del fuera de campo, y de uno especialmente importante para nosotros en este artículo, el de la profundidad de campo. A través de la combinación en el uso de una serie de parámetros técnicos distancia focal, apertura del diafragma y velocidad de obturación- la profundidad de campo permite controlar la nitidez de todos los elementos que forman parte de la composición de la fotografía. En el cine esta técnica permite el tratamiento de escenas enteras en un solo plano renunciando a los efectos dramáticos del montaje que, como sabemos, implica un control de la fragmentación y una teórica mayor continuidad en la superficie de la parte de la realidad que se nos ofrece en el encuadre. Según Bazin (1966) el espectador adquiere una relación más próxima con la imagen de la que tiene con sus supuestos referentes en la realidad, solicitándose una postura más activa, al obligarle a "captar sensiblemente la continuidad del acontecimiento" (Talens 1991, p. 100). En este sentido este recurso constituye "un procedimiento de producción de sentido alternativo al montaje en sentido estricto" (101), revelador así, de paso, del gran truco del código realista en el MRI (modo de representación institucional). Este recurso funciona, lógicamente, en el arte fotográfico que fundamenta parte del lenguaje cinematográfico, la fotografía. Así, JT supo explotar en su uso metafórico de esta profundidad de campo la falta de jerarquía y la colectividad de las imágenes en su percepción por parte del espectador, simulando además una mayor "naturalidad" en la experiencia de visión del mismo receptor-lector. Los elementos, escenarios, personajes o puntos de vista que pueblan un libro como Profundidad de campo se relacionan entre sí en el mismo plano, del mismo modo en el que, en el caso del cine, los cuerpos y los sonidos no se aíslan en los planos-secuencia de directores como Berlanga o Tati. Ahora bien, si la profundidad de campo tenía un carácter supuestamente más objetivo en aquel libro (Talens, 2001)9, en Lo que los ojos tienen que decir se reviste de una perspectiva más interior,

9 Como era evidente, por ejemplo, en poemas como "Mar y luz", "Situaciones" o "Polvo de estrellas muertas". 
superponiendo los planos de lo que el punto de vista recoge con lo que el sujeto poético imagina o recuerda (veremos algún ejemplo en la sección 4).

Desde La mirada extranjera, con el fotógrafo Michäel Nerlich (1986), e incluso antes, en su segundo libro, Una perenne aurora (1970) o ya en Purgatori (1982), con dibujos respectivamente de Tomás March y Doménec Canet, hasta llegar a Según la costumbre de las olas (2013), con fotomontajes de Clara Janés, Jenaro Talens ha explorado lo que llama un espacio tercero, un modo de relación entre palabra e imagen donde, en principio, ninguna de las dos se subordina a la otra, según las relaciones sintácticas predominantes en la tradición del ut pictura poesis ${ }^{10}$. Ni la écfrasis, ni la ilustración, sino un ente nuevo, una modalidad intersemiótica distinta que fue dada en llamar iconotexto, un término (con su concepto asociado) que nosotros interpretamos en la dirección de la imagentexto de William J.T. Mitchell (1994). Según este concepto no se entienden ni la poesía ni la fotografía (representantes en este caso, respectivamente, de las artes verbales y visuales) como prácticas discursivas homogéneas $\mathrm{y}$ autónomas, aislables la una de la otra y, eventualmente, sujetas a una intersección o combinación que mantuviera, en cualquier caso, su esencia particular intacta. La imagentexto, en tanto que categoría dialógica, no sólo designa la impureza de todo arte o práctica cultural, sino la rozadura o interferencia entre lo verbal y lo visual, "Ruptura, síntesis, relación" (Mitchell, 2015, p. 45) ${ }^{11}$.

\footnotetext{
10 Para una revisión de los iconotextos en la obra de Talens, véase Fernández Serrato 2015, pp. 84-240.

${ }_{11}$ Mitchell actualizó el sentido triple de este concepto en "Imagen X Texto": "Estamos obligados a abarcar estas tres posibilidades. Por un lado, están lo que podría llamar manifestaciones "literales" de la imagentexto: las narrativas gráficas y los cómics los textos fotográficos, los experimentos poéticos con voz e imagen, los collages o la tipografía en sí. Por otro lado, están las versiones figurativas y desplazadas de la imagen-texto: las divisiones formales de narrativa y descripción, las relaciones de visión y lenguaje en la memoria, el anidamiento de imágenes (metáforas, símbolos, objetos concretos) dentro del discurso, y el anverso, el murmullo del discurso y el lenguaje en los medios gráficos y visuales. Y por último, hay una tercera cosa: la brecha traumática del espacio no representable entre las palabras y las imágenes, lo que intenté designar con la "/" o barra oblicua" (2012, p.45), es decir la imagen/texto.
} 


\section{Metodología: La imagentexto en Lo que los ojos tienen que decir}

Es este un libro que se concibe desde su raíz en clave dialógica, en búsqueda de ese "tercer espacio" donde la imagen "no es la impronta metaforizada de una descripción", ni "lo escrito es una glosa de la imagen" (Talens, 2014, p. 12). En su entrevista con Fernández Serrato a propósito de este libro, JT recordaba la génesis del mismo, originalmente un proyecto a "tres voces", donde un músico (Santiago Auserón), un fotógrafo (García-Alix) y un poeta (él mismo), reflexionaban colectivamente sobre las claves de la creación, el sonido, la imagen, la palabra. Aquel proyecto quedó inacabado, por dudas de García-Alix (Fernández Serrato, 2015, p. 280) respecto a su contribución teórica al mismo, y acabó convirtiéndose en una colaboración a dos bandas donde el poeta logró algo que pocas veces había conseguido. Así describe el proceso de colaboración:

Los primeros poemas surgieron de mi lectura de sus fotografías, de lo que me sugerían a mí; pero cuando llevábamos una docena o así, él se metió de lleno para poner orden en el material para el libro y empezó a quitar parte de las fotos que habíamos acordado que irían para hacer otras específicas a partir de lo que los poemas le sugerían a él con lo cual el diálogo se estableció de la manera que desde el principio de mi carrera siempre había querido que fuese: un poema sugiere una imagen, la imagen sugiere un poema, el nuevo poema sugiere otra imagen y así sucesivamente; hay una especie de intercambio continuo, que es lo que al final ha salido (2015, p. 281).

Nos encontramos, por tanto, ante un caso que responde al corazón de la intermedialidad, entendida en sentido deconstructivo y auténticamente dialógico. La intermedialidad, desde nuestra perspectiva, no es solo o tanto el conjunto de fenómenos o prácticas artísticas que suceden "entre los medios", como también la categoría que identifica la pluralidad interna de cada medio y, más allá, la condición de posibilidad de la existencia y funcionamiento de cualquier medio (Sánchez-Mesa/Baetens, 2017, p. 9). Hasta tal punto se daría esta condición que la poesía podría entenderse como el espacio privilegiado, derivado de esa misma fuerza intermedial, para escapar del 
dominio tradicional del "logos", como así lo constata el mismo Talens al declarar que el pensamiento no tiene por qué reducirse a la racionalidad de los conceptos (Fernández Serrato, 2015, p. 282). En efecto, la relación intermedial entre escritura y fotografía, entre lenguaje verbal escrito e imagen fotográfica, no solo se produce en cuanto inter-referencia sintáctica de palabra e imagen sobre el díptico que conforma cada doble página del soporte libro, en el sentido considerado por Kibedi-Varga en su método semiótico-sintáctico (2000). Tampoco se limita al grado de "combinación medial" con el que Rajewsky se refería a aquellos objetos mixtos en los que se dan cita distintos medios o formas mediales de articulación (2005, p. 51). Esta relación es más radical de lo que esas dos dimensiones o perspectivas (semiótica y comparatista) puedan señalar. El propio término con el que JT viene denominando a esta serie continuada de libros desde La mirada extranjera (1986), iconotextos -serie de la que nuestro libro constituye el número quince-, ya nos indica que en este proyecto dicha relación intermedial es constitutiva de un género híbrido, mixto, perteneciente a la estirpe de la imagen/texto (Mitchell, 1994 y 2019) en la que, siguiendo el principio derridiano de la differánce, tanto escritura poética como imagen fotográfica portan "en sí mismas" la huella de la otra ${ }^{12}$.

Es la segunda vez, por tanto, según constata el propio Talens, tras Según la costumbre de las olas (con fotomontajes de Clara Janés, 2013), que la vinculación con las imágenes no se produce "a posteriori", es decir independientemente de la "contraparte icónica", a través de una "operación de montaje" (2014, p. 13). Esto no quiere decir que todas las fotografías o los poemas fueran tomándose o escribiéndose en un proceso paralelo (sabemos que algunas de las fotos están fechadas con anterioridad a esta colaboración) pero sí que, como dice Talens, la producción de este iconotexto supone un nivel de colaboración y, por tanto, de intermedialidad, superior al de otros

\footnotetext{
12 Desde una perspectiva paralela se mueve la propuesta de Bomholt (2018) de emplear el concepto de parallax, al modo que lo hace Slavoj Zizek, para comprender la función suplementaria respecto al texto de Walter Benjamin de las fotografías de AGA en El truco preferido de Satán (Benjamin, 2012), texto adoptado para una lectura más poética con la edición de Talens para Salto de página.
} 
iconotextos anteriores, siempre dentro de un proyecto orientado a "desmontar las nociones de autorretrato o autobiografía". Dichas nociones deben entenderse aquí en tanto que constituyan un "punto de vista" (hablar "sobre uno mismo" pero no "de uno mismo"), como una "proyección" para hablar sobre lo que a uno le pasa a propósito de lo que les pasa a otros que estarían en las mismas circunstancias.

El diálogo aquí concitado no es, por consiguiente, entre AGA y JT, sino más bien entre esos dos sujetos enunciativos que "eran y no eran" los firmantes del libro; "lo eran" por partir hasta cierto punto de una voluntad consciente de autorreflexión sobre sus respectivas trayectorias artísticas y personales. Y "no lo eran" porque el punto de partida de las "supuestas" autobiografías no eran "anécdotas propias de cada memoria particular" sino "la respuesta de cada una de ellas a un estímulo proveniente de la que era propia del otro" (Talens, 2014, p.13). De este modo, JT confiesa que uno de los aspectos que más le fascinan del trabajo de AGA es "la voluntad constante de reflexividad" (que no se atreve a llamar "metafotográfica"), la necesidad de "ver(se) y pensar(se) cuando mira por el visor" (2014, p. 15). Su valor, para JT está menos en su valor documental, en su dimensión referencial, que en la de su pensamiento. De este modo, el poeta se refiere el testimonio del fotógrafo sobre el motor de su acción, cámara en ristre por la calle, disparando cuando "sentía miedo". El mundo, que siempre se cuela (tanto en una foto como en el poema) se convierte así más en síntoma de "una mirada que (se) interroga y constata lo que ve, sin caer en la tentación de juzgarlo" (p. 15).

Por otro lado, Talens igualmente "intuye" que los retratos de AGA se basan en una experiencia similar a la que él construye en sus poemas: retratos de "desconocidos", aunque el rostro sea el suyo, de tal modo que de la "apariencia exterior del otro" surja lo que es invisible a nuestra percepción, es decir, lo que ignoramos de nosotros mismos. No dejarse "fijar" el interior, cambiar de máscara, de gesto, de actitud... Esta reflexión compartida, este "espacializarse" en un libro que es un iconotexto, deviene así en una estrategia, muy eficaz en nuestra opinión, para defender la inestabilidad de la mirada, la movilidad y viveza de la percepción y por tanto de la propia 
identidad. En el texto "liminar" que estamos glosando, Talens visita la inevitable imagen del espejo, de raigambre inequívocamente dialógica: "nos construimos a nosotros mismos como imagen para los demás” y, a partir de ahí, enuncia con precisión lúcida la explicación de este proyecto: "Retratar es desestabilizar la supuesta totalidad cerrada del fantasma que nos representa, obligándole a quitarse la máscara” (2014, p. 18).

A fin de cuentas, lo importante en ambas prácticas de estas "artes hermanas" (acudiendo al motto clásico) no es para JT el tiempo, sino el "espacio como lugar donde proyectar y reconocer esa mirada autorreflexiva" (pp. 18-19). El poema se entiende y trabaja así no tanto como "recuperación" del tiempo perdido (sujeto a la inevitable nostalgia, o a la elegía melancólica) sino como "inscripción" en la "presencia de una ausencia", haciendo visible lo invisible (huella fotográfica) y sonoro el silencio (aquí la poesía). Y es que, como el propio Talens no deja de subrayar, en poesía (literatura) suele confundirse el "yo gramatical” con el "yo persona”, cosa que en fotografía no sucede (p. 20). En realidad, y la historia de la poesía enseña bien esto, "toda literatura es autobiográfica, como toda fotografía es un autorretrato, sin que ni una ni otra asuman como imprescindible la necesidad de convertir al autor en protagonista de nada ni de asumir como normal confesionalidad” (p. 21).

Tal vez no sea una casualidad, en cualquier caso, que junto a este motivo central de la "autorreflexión" para constatar la imposibilidad de una presentación confesional o directa del “yo", esté el tema de la muerte, fundamental en la obra de AGA, evidente en muchas de imágenes muy desoladoras así como en alguno de sus textos. En el caso de JT, ya estuvo en el origen del iconotexto anterior con Clara Janés, y regresa aquí, sobrevolando el esfuerzo de decir lo ignoto, el lugar del que no se vuelve y el momento límite del tiempo. Así leemos, por ejemplo, en "El enigma de la claridad”: “¿Cómo dejar constancia de su incertidumbre para aquellos que amaren cuando muera, cuando todo termine y todo esté por empezar?” (García-Alix/Talens, 2014, p. 84). 


\section{Estructura y ritmos intermediales de la obra}

Sabemos que la música es un modelo muy importante en la poesía de Talens. Es el "arte más sublime", liberado de la semántica convencional, como de algún modo puede serlo la pintura que no se sujeta al figurativismo. En este sentido observamos que el libro se estructura musicalmente en dos partes, enlazadas por un intermedio (a modo de programa de un concierto). La primera parte ("Lo que los ojos tienen que decir"), a su vez, consta de cinco partes, cuyos títulos sugieren un lenguaje, sin embargo, guionístico, propio de ese texto igualmente intermedial, el guion cinematográfico (texto verbal que no se lee como literatura, sino que existe como pretexto para imaginar la puesta en escena de una película): "1. Interior. Noche"; "2. Exterior. Día”; "3. Cuaderno de Migjorn”; “4. Exterior Día”; "5. Interior. Noche”. Percibimos de este modo que el diálogo intermedial con la fotografía, se refuerza así desde una imaginación más cercana al cine, dando cabida o simulando una estructura de relato, que se escamotea en la fragmentación de las piezas, refractarias a toda forma de causalidad o consecutividad. Este ritmo y oscilación entre la noche y el día se subraya con la alternancia o cambio desde el poema en prosa, que domina las partes impares del libro, al del poema en verso, que lo hace completo en la segunda y cuarta partes del libro, ambas tituladas bajo el signo de la luz ("Exterior. Día”).

En cuanto a la dimensión editorial del libro, la composición sobre el díptico que constituyen cada doble página (par-impar) de las 37 fotografías y otros tantos poemas ${ }^{13}$, es muy importante el hecho de que se persiga un ritmo compositivo gracias al orden y disposición de poemas y fotografías, alternando la posición, izquierda o derecha, par o impar, de cada uno de los dos tipos de componentes. Se desestabiliza así cualquier orden que pueda imprimirse sobre la mirada del lector que contempla, o del espectador que lee, a partir de una prioridad o jerarquía entre los dos tipos de lenguajes o textos entrelazados en el libro. Bien es verdad que, el logos del poema, a

${ }^{13}$ En este equilibrio compositivo hay que apuntar que, en la parte II del libro, al menos tres poemas se componen de varias secciones ("Un cielo de cartón", "Far From Home" y "La exactitud de las mareas") lo que provoca una mayor presencia de la palabra poética sobre la imagen fotográfica al final del libro. 
través de sus mismos títulos, ejerce cierto efecto centrífugo respecto a las fotografías al abandonar estas sus títulos originales ${ }^{14}$. Posiblemente, como Antonio Monegal señalara a propósito del concepto de poesía vanguardista (en el caso de "La rueda de los tres amigos", Lorca, Dalí, Buñuel), en este caso fotógrafo y poeta comparten un concepto de su quehacer creativo que es común a sus dos lenguajes, el hecho poético mismo y, en concreto, el concepto de “imagen” poética (Monegal, 1998).

Una característica importante de este ensayo de iconotextualidad (intermedialidad) desplegado en Lo que los ojos tienen que decir es la voluntad de evitar lo que podríamos denominar el prurito ecfrástico, es decir,

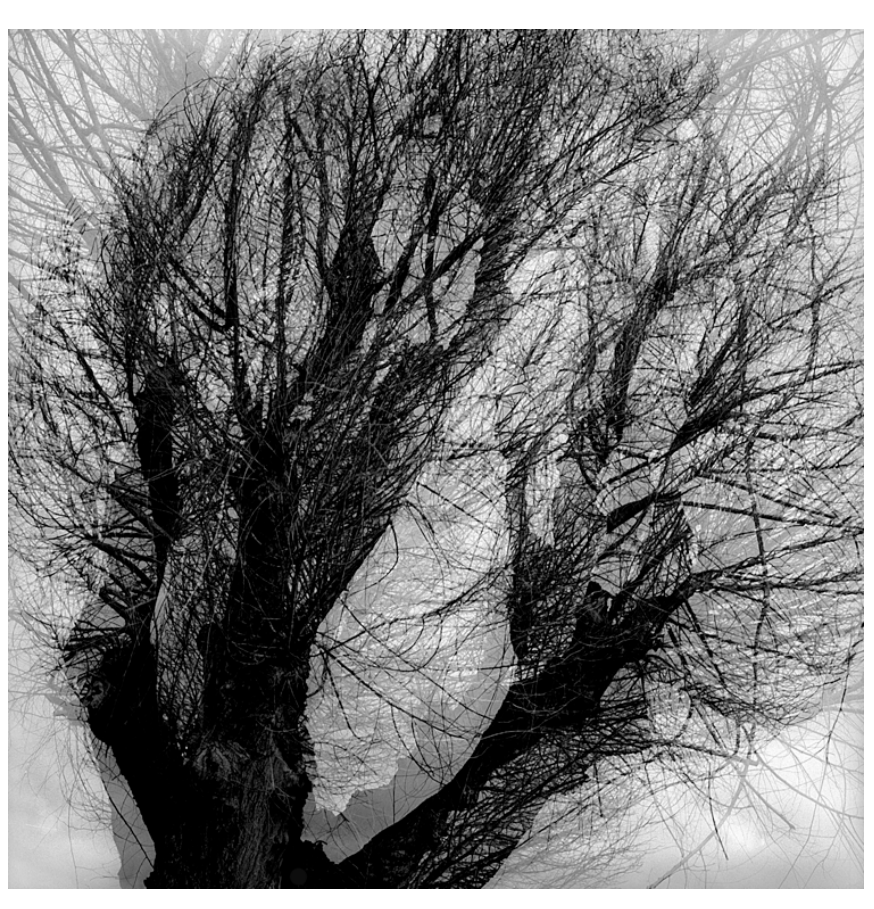

F1. Triste rostro de melancolía, 2014. el impulso hacia la descripción verbal de la imagen fotográfica, sea con un aliento propiamente intermedial ("lograr alcanzar las potencialidades de evocación o sugerencia del arte hermana"), sea con un impulso elegíaco que, por lo demás, es inexistente en Talens (ajeno al sentimentalismo) e igualmente difícil de identificar en las fotografías de García-Alix. A veces incluso se percibe cierta ironía, como en sordina, tal y como sucede en la sección "Intermedio" con el poema "Ensayo de descripción", (F1) donde lo ecfrástico se diluye apenas pasadas las primeras líneas, insistiendo en el "fuera de campo", donde un escenario y un relato mínimo emergen, rodeados de misterio, abandono y soledad a propósito de un olmo que, en la fotografía, aparece sobreexpuesto,

14 Incluidos en este artículo a través de los pies de las fotografías. 
fantasmagóricamente, sobre sí mismo, generando una suerte de fundido que acentúa la sensación de infinitesimal nervadura o sistema circulatorio vegetal, aumentado y duplicado por la superposición fotográfica.

\section{Lectura intermedial de la imagentexto de este libro}

Para terminar, vamos a ensayar la lectura de algunas de las imágenestexto del libro que nos ocupa y comprobar el funcionamiento de este iconotexto. Lo haremos a partir de la identificación de unas categorías intermediales a modo de herramientas interpretativas, entre las cuales recuperamos los tres conceptos que establecíamos más arriba como constantes comunes a las poéticas de ambos artistas. Nos limitaremos a escoger algunos de estos dípticos (foto-imagen, imagen-texto) especialmente representativos.

a) El personaje/sujeto y su configuración discursiva (¿quién mira, quién habla, quién es mirado o recordado o descrito?) y la reflexión sobre una (im)posible autobiografía o autorretrato y, en relación a ello, la presentación

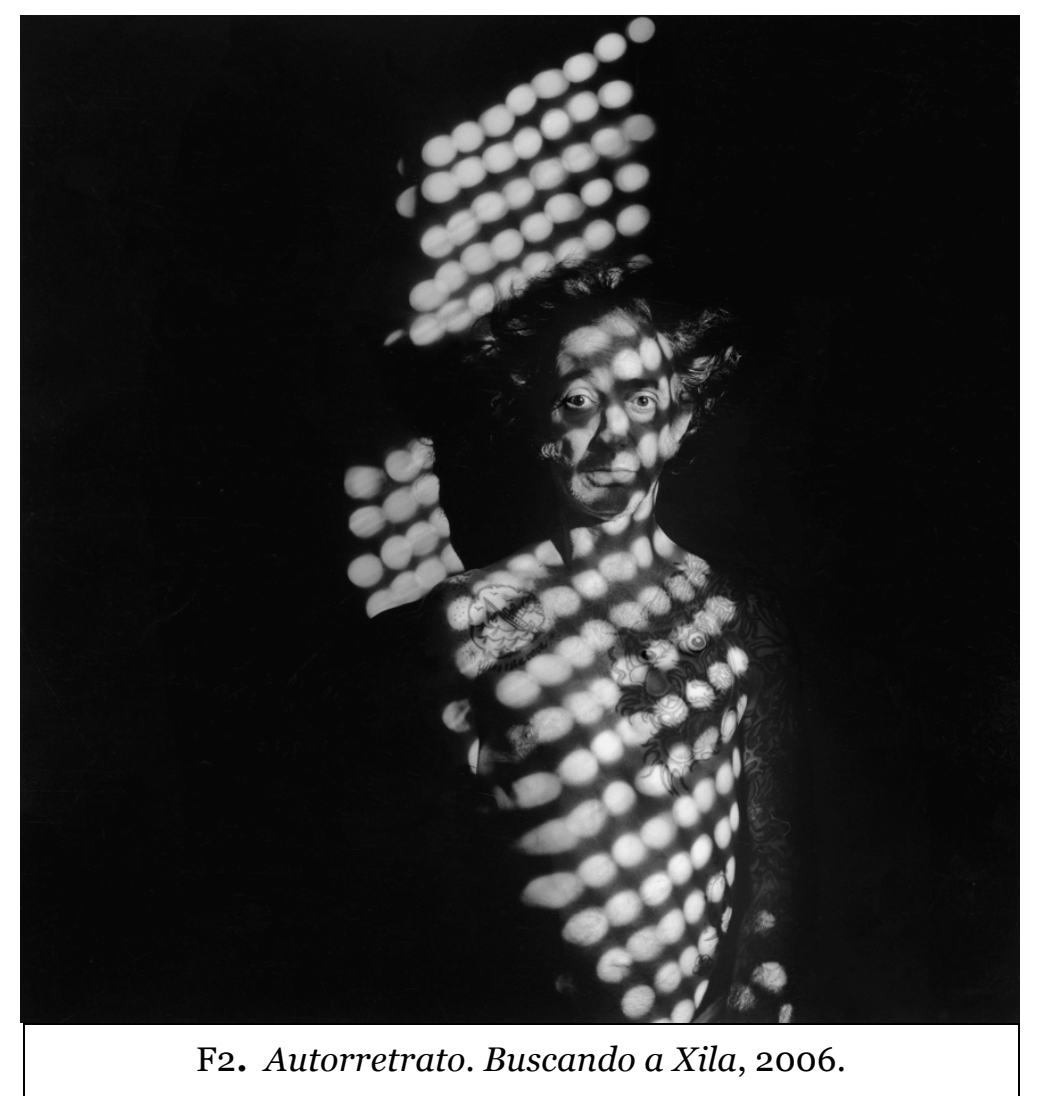

o evocación del cuerpo. La importancia de esta categoría se puede corroborar en su aparición en el mismo "Prólogo" del libro, cuyo único poema, "Xila, un arranque muy poderoso con un autorretrato "real" de García Alix (página par) que ofrece el primer y último 
rostro reconocible de todo el libro, tamizado por la retícula de una celosía que se interpone entre el objetivo y el torso (desnudo y tatuado) de un hombre que mira con los ojos bien abiertos, tal vez algo sorprendidos, en una foto de este alter ego de AGA, un desdoblamiento que utiliza a veces en sus textos para mejor atrapar el drama del autor [F2]. El poema, por su parte, metaforiza en forma interrogativa y con el proceso de revelado "ese lugar del que no se vuelve", el purgatorio... "antes de toda noche y de todo amanecer": "[...] silencio en torno y la cubeta en que, / poco a poco, la luz / construye el revelado de una presencia, la presencia ausente donde el sol se asoma / con miedo y furia al interior, [...]".

b) El deseo de ver como eco del deseo acceder al "imposible" de lo real - en términos psicoanalíticos (contracampo en cine) - se materializa a través del encuadre de la mirada y su par, el fuera de campo, como técnicas básicas de la mirada constructora, sin olvidar su relación con las formas del silencio (lo

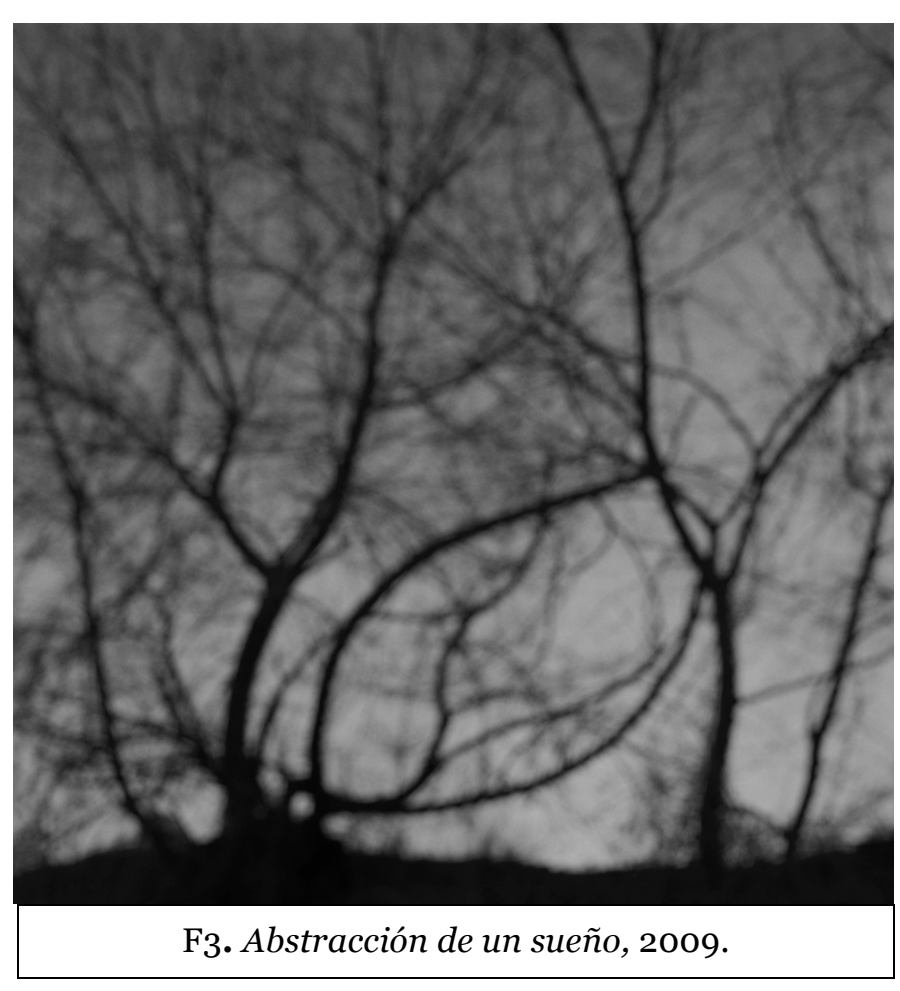
no dicho o que queda más allá de los contornos, tanto del poema como de la fotografía). De este modo, abriendo la parte IV del libro en "Ignora cómo pero no por qué" $\left[\mathrm{F}_{3}\right]$ observamos la imagen desenfocada de lo que parece ser un árbol, pero también podría ser una raíz invertida y junto a ella (página impar) leemos un poema de una condensación imaginaria y simbólica extraordinaria. Nos movemos básicamente guiados por la intuición que esas imágenes generan en la lectura. Persiste el halo de la pregunta por el no ser, "¿Tiempo o espacio? ¿Pervivencia? ¿Dónde?” Con unos versos finales que, de modo extraordinario, rompen con 
el contrapunto entre palabra e imagen en este libro ("Solo raíces en la nervadura / que el ojo inscribe / sobre el cielo / gris"), la imagen de unas ramas, desenfocadas, captadas desde un punto de vista bajo, que se extienden sobre el cielo gris de fondo. "El ojo" que inscribe esa "nervadura" es la mirada del fotógrafo, pero es también la mirada del poeta y también el ojo o lente de la cámara.

c) La profundidad de campo15. Uno de los pocos poemas en que cabe identificar dicha técnica, literal en la fotografía, y figurada en la poesía, es "En las esclusas del paraíso" [F4]. La fotografía, en página par, es un contrapicado sobre las ramas desnudas de un gran árbol, o de varios entrelazados, desnudos de hojas y de leñosos nudos, con los frutos aun pendiendo, cielo gris, como un gigantesco rizoma lanzado hacia el cielo. La nitidez entre los distintos planos de esa red de ramas es total. El poema, en la página impar se abre con la acción de "mirar" en

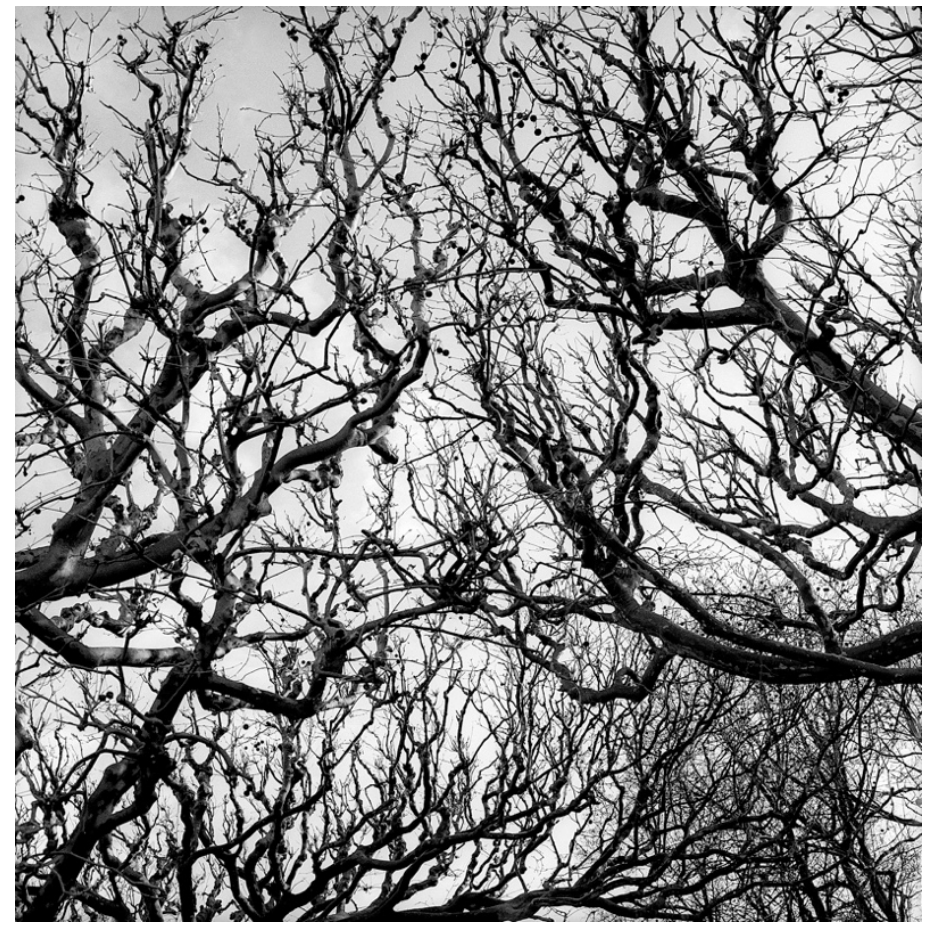
F4. El purgatorio II, 2008. tercera persona ("Mira"), "las piedras del cercado, el muro derruido [...] el musgo y los yerbajos", para enseguida pasar al espacio del "imaginar" "el verde de los árboles [..., el viento o la lluvia", dejando espacio incluso para "lo que falta": "los pájaros, el piar que no escucha". La mirada percibe "ramas desnudas" en las que se posan "matojos en bandadas" y da paso al "recuerdo" de un "pentagrama donde anotar los ritmos de un silencio tan improbable

15 Véase la sección 1.3. para recordar el fundamento técnico fotográfico de esta técnica y su correlato poético. 
como atronador”. La pregunta final, “¿Qué hacer con todo esto? ¿describir un paisaje? ¿La superficie de su rostro vuelto densidad?” nos conduce al centro de la diana del proyecto del libro en sí, la posibilidad imposible de "un autorretrato", casi diríamos que "brutal", pues estamos en un jardín desolado, enmohecido y silencioso donde se impone el silencio ("le hacen daño los pájaros que faltan, el piar que no escucha”) y lo que el cielo aporta ya no es lluvia ni gracia, sino "humaredas sin control", "nada"... "simples rescoldos de un azar difuso que nunca confundió con el destino...”.

d) La luz es una categoría compleja de aislar como fundamento poético en este ejercicio de análisis intermedial al ser una condición física o materia prima esencial para la fotografía mientras que en poesía constituye un símbolo, si bien fundamental. En el poema "Coro" la fotografía (F5), en página impar y desde un punto de vista bajo, nos ofrece una figura difuminada en su sombra vibrante dentro del mar, sobre la estela brillante del sol (¿̇ocaso? ¿amanecer?). El sonido que evoca el título (“Coro") se

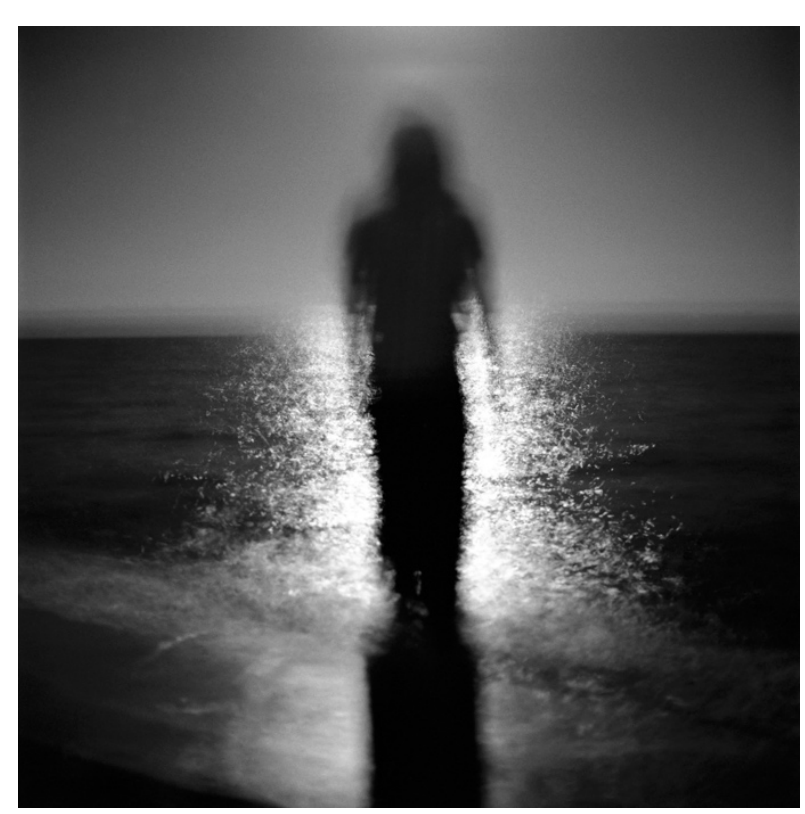

F5. Sin título, 2008. corresponde con la vibración del efecto técnico de la luz sobre la imagen y las palabras: "Quise escribir en mi cuaderno como pinta el aire...”, invocando figuras recurrentes en el libro ("igual que canta el pájaro en la rama cuando la aurora inscribe un haz de aurora en el azul del cielo"), como también a la muerte ("Desde el silencio que me aguarda [...] la vida que he vivido no me debe nada; tampoco debo nada a la que no viví. Este cuerpo en que habito se mantuvo a mi lado y antes de que su nada me disuelva observo con gratitud el mundo de los otros"). Frente al pasado ("Fue también mío y lo gocé"), encontramos un final sereno, puro presente subrayado en "la luz hermosa de este atardecer". 
e) Determinados temas figurativos como el pájaro, el mar, el árbol, el cielo. Aunque ya hemos mencionado alguna de estas apariciones en los comentarios anteriores, escogemos aquí una de las figuras más potentes en la fotografía de García-Alix, los pájaros, para hablar de "El lenguaje secreto de los pájaros" y "Pájaro o encrucijada" [F6] El primero es otro extraordinario poema a la muerte ("En la ecuación sumaria de la fantasía, la música se sirve del silencio para pensar la muerte a su manera”) mientras que, en página

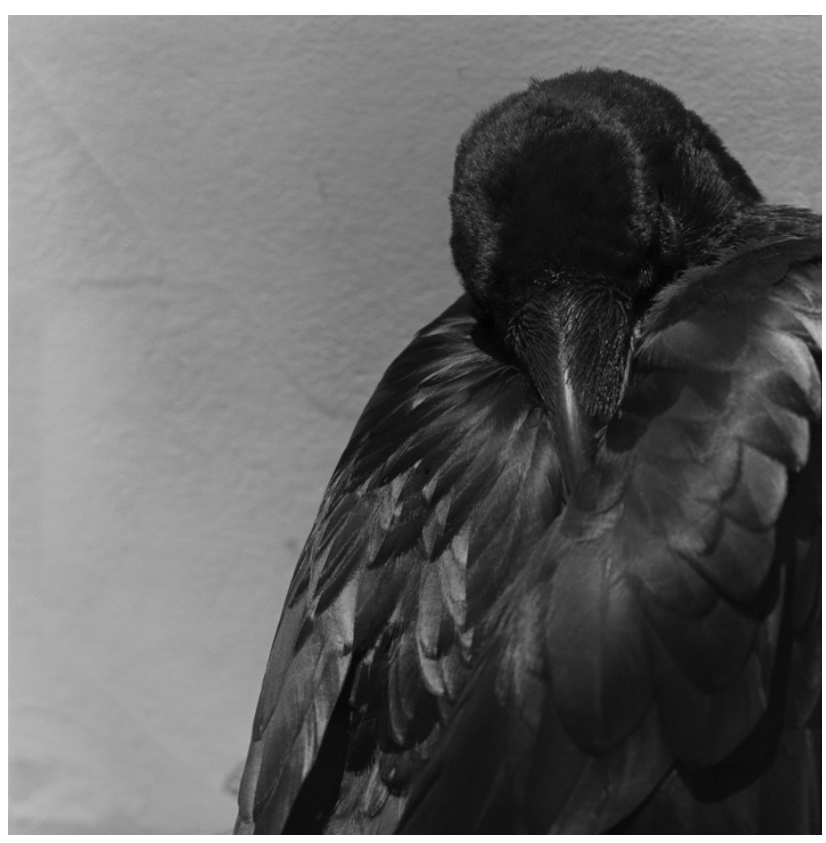

F6. Lo que los ojos tienen que decir, 2012. impar, una de las sobrecogedoras fotos de GarcíaAlix descontextualiza la pequeña figura de un pájaro muerto sobre un espacio blanco: "La noche, mientras tanto, sigue su curso sin cantar, sin nada". La segunda fotografía la protagoniza la negrura de un cuervo (¿muerto, dormido?), una imagen en primer plano muy contrastada y de gran fuerza que nos remite a "la no conciencia de la muerte, inmóvil, sobre la geométrica simplicidad del sol naciente [....]" configurándose en breves trazos y, en este caso, diluyéndose en una poderosa metáfora de ese sueño, tal vez de la muerte: "Solo el fluir borroso de la imagen / dice el cuerpo sin cuerpo / de una noche / interior".

f) Referencias directas entre las dos artes a veces a través de las imágenes desplegadas en el poema, otras por medio de la "alusión" a determinada técnica específica del "arte hermana" a través de los mismos títulos de los poemas. Esto sucede, por ejemplo, en "Si al menos pudiésemos decir" (F7) donde la imagen nos deja ver un mural con un andrógino rostro pintado sobre enlucido borrado, con un saliente que forma, en un sugerente contraste, un pezón que hace de esta fotografía casi un objeto "táctil" que 
estimula a sentir la rugosidad del desconchado, la materialidad del muro. El poema se abre con una metáfora explícita en los primeros versos: "Fuera de campo estábamos al sol, / como seres cautivos de una fotografía/ Es una imagen fija y sin profundidad, / que no deja asomarse a su interior, a quien está sentado al fuego / [...] ". Es una ocasión extraña en el conjunto del libro por cuanto se convierte a la tercera persona en femenino en personaje protagonista de una experiencia construida o ficticia: "Pongamos, por

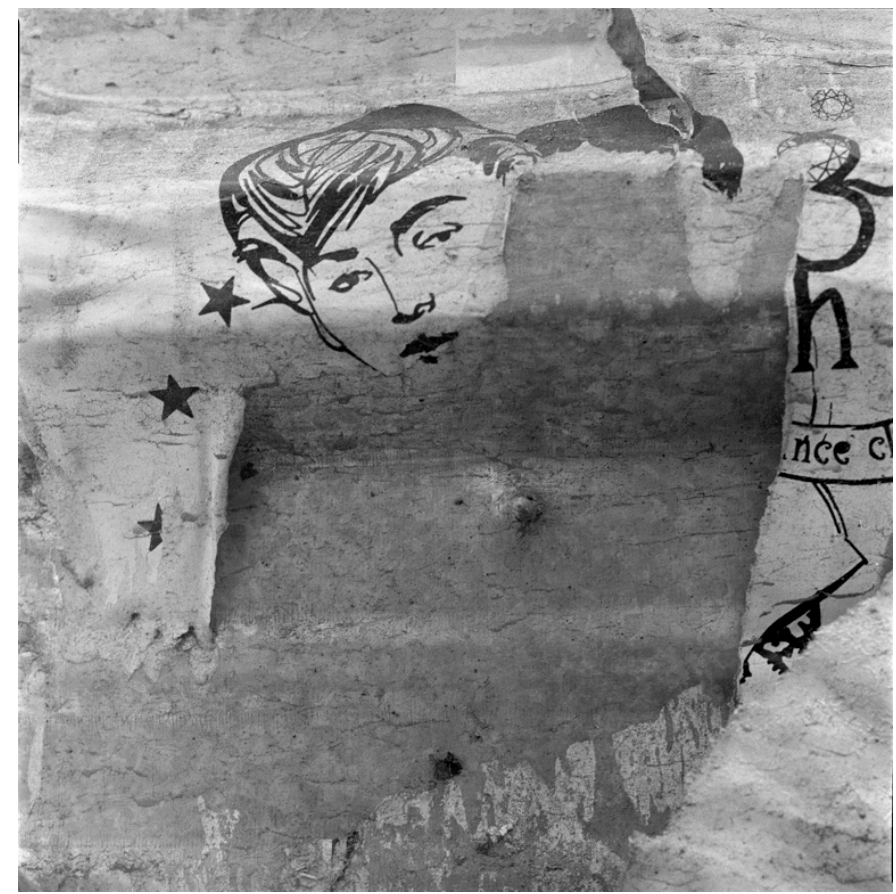

F7. Albertito, 2009. ejemplo, que se escucha el tañido apagado de una iglesia cercana". Arriesgando una interpretación posible, esta imagentexto de la figura de torso borrado y su poema pueden sugerir notas de infertilidad ("refugio que nunca fue, la sangre fluye ahora / fingiendo una heredad que no responde") de la mujer que no tendrá descendencia.

En esta cala ensayada llegamos así al Epílogo y el final del trabajo bivocal de la mirada constructora con un último y breve poema, significativamente titulado "Punto de fuga" [F8]. El mar como protagonista, fuera de foco, con abundante grano y falta de contraste. Es, por tanto, un principio geométrico el que da título a la imagen que cierra el libro, esta vez, si no esperanzada, sí voluntariosa al máximo: "El fluir de las olas contradice la muerte / con una oscuridad a medio hacer". La fotografía de AGA parece corresponderse en buena medida con el poema cuya imagen brumosa emplaza al lector en un "allí" por vía del oído: "Se oye el chisporroteo de la espuma / y una niebla 
sumisa que avanza paso a paso / filtra un difuso resplandor”. Y la imagen final, ambigua, "La noche abre los ojos sin pestañear” nos devuelve, una vez más al campo semántico de la mirada, esta vez sobrehumana (mirar de la noche) en un certero símbolo de la muerte que, sin embargo, cuenta con la suficiente ambigüedad como para no ubicarse en el cierre de nuestros ojos, sino en la apertura de los de la noche. El fluir de las olas ha venido en ayuda de esta imagen de clausura (contradictoria de la muerte) y nos deja un asidero, toda la fuerza de la poesía, en su suprema fragilidad. La mirada, finalmente, es capaz de "construir" (el punto de fuga es una perspectiva, una tecnología humana del artista que mira) ese espacio del poema, del mismo modo que el fotógrafo ha construido el de la imagen fotográfica, y por tanto, puede entenderse también como otra dimensión de esa noche, que "abre los ojos sin pestañear”.

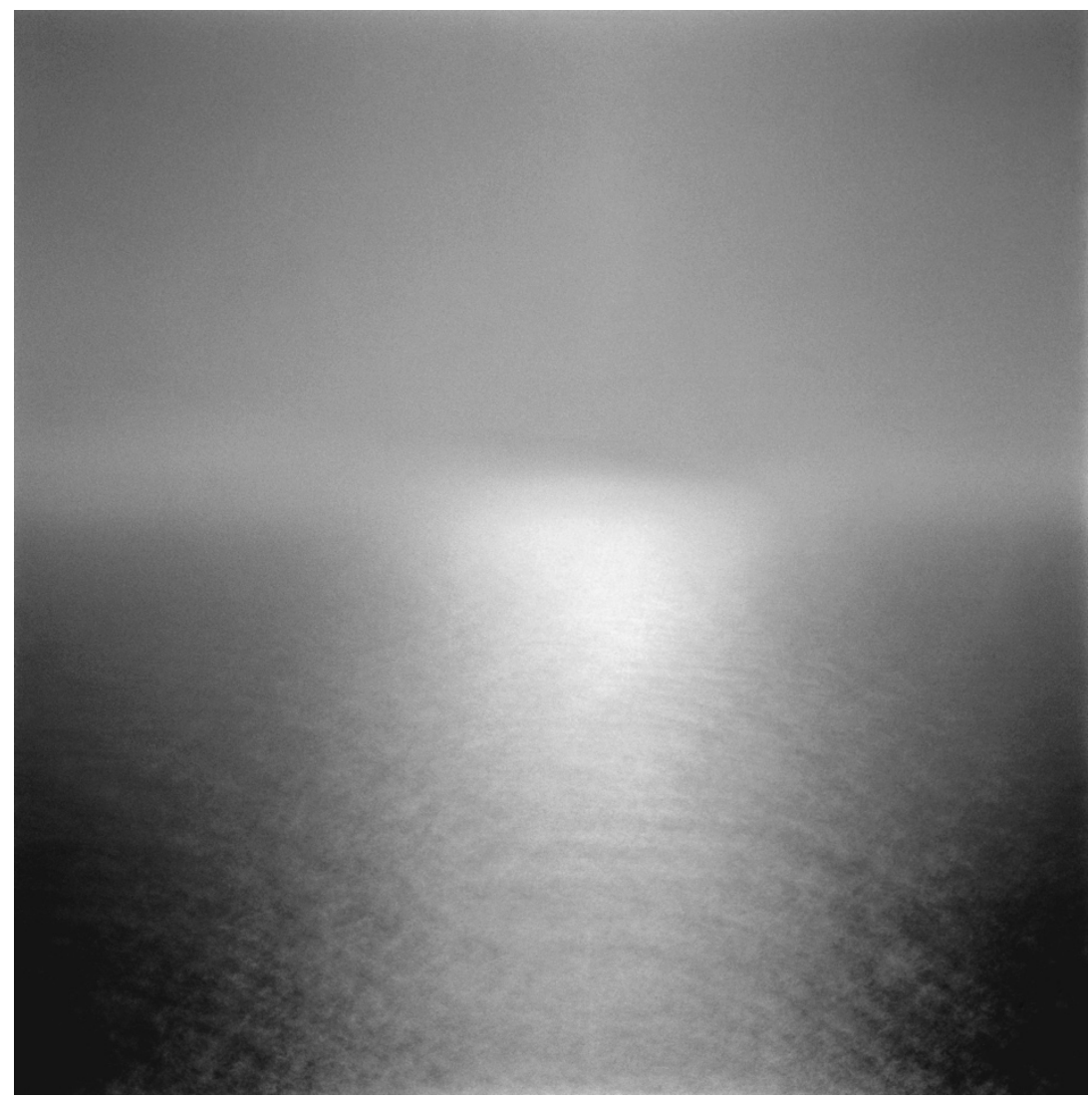

F8. La tumba del marinero, 2001. 


\section{Conclusiones}

Según el principio de intermedialidad radical que hemos manejado en este texto ("no existen los medios puros", "todos los medios son medios mixtos") hemos podido vislumbrar la potencia y riqueza de sentidos que la fotografía puede y de hecho dispara en asociación dialógica con la poesía. La noción de imagen(-)texto (Mitchell 1994, 2019) y el mismo concepto de iconotexto (desarrollado por Talens) se han revelado como plenamente operativos para comprender la especificidad de la colaboración acaecida en este caso, enriqueciendo el dominio del comparatismo interartístico en su versión más reciente de comparatismo intermedial.

Hay más formas de colaboración entre imagen fotográfica y palabra literaria que la que, tradicionalmente, ha reducido a la primera a objeto explicado o ilustración de la segunda. Hay más opciones que la écfrasis o la ilustración. De hecho, experimentos editoriales como el libro que nos ha ocupado demuestran la riqueza de una concepción más basada en la diferencia y el roce entre imagen y palabra, tanto en su génesis como en el programa de su estructura y los ritmos que acierta a generar a distintos niveles en formato códice. Aun así, es justo señalar que la palabra, tanto a partir del aparato teórico que precede a las imágenestexto, como en el propio equilibrio cuantitativo en las páginas del libro, acaba dominando de algún modo a la imagen.

Por otro lado, Lo que los ojos tienen que decir se convierte en una suerte de manifiesto (implícito) de una poética (teoría de la creación artística) resistente al dominio del realismo y a los conceptos dominantes de autobiografía y autorretrato, explorando no solo en los recursos técnicos y formales de cada lenguaje o medio material (las personas gramaticales, la métrica o los recursos retóricos y rítmicos del verso o la prosa, junto a la profundidad de campo, el fuera de campo o el encuadre y la exposición a la luz) sino en las oportunidades que los límites o intersticios entre ambos proporcionan a sus creadores: subjetividad y discursividad, la mirada 
constructora, el deseo, la imagen poética, o una serie de figuras de alto contenido simbólico son los pilares en los que hemos basado nuestra lectura.

Llamamos la atención, para finalizar, sobre la cita del Tractatus logicophilosophicus de Wittgenstein que cierra el libro. Esta cita, además de emocionante en su certera puntería, es un asidero más en esa autoexplicación en que consiste el libro. El recurso del filósofo a la mirada confirma el título y la poética de ambos artistas implicados en este libro: "Nuestra vida es tan infinita como ilimitado nuestro campo visual" (2014, p. 139). Igualmente relevante y sintomática de este proyecto puede ser la imagen escogida para la portada del libro, parte de la imagentexto "Pájaro o encrucijada", el sueño del pájaro negro, el cuervo recogido en sus brillantes alas, subrayando el tema de la muerte ("[...] tras la pupila inerte que no ve (¿qué sueña?) / la no conciencia de la muerte, inmóvil / sobre la geométrica simplicidad / del sol naciente en el tejado [...] Fotografía y poesía abiertas al misterio en el espacio de las páginas de un libro, construyendo juntas una realidad "otra" que está más allá, o más acá, de las figuras y las personas (o personajes) que habitan ese espacio.

\section{Referencias bibliográficas}

Barthes, R. (1982). La cámara lúcida: nota sobre la fotografía. Trad. Joaquím Sala Sanahuja. Barcelona: Gustavo Gili.

Benjamin, W. (2012). El truco preferido de Satán. Fotografías de A. GarcíaAlix; trad. V. Forés y J. Talens (pról. J. Talens, epíl. A. Combarro). Madrid: Salto de página.

Bomholt, M.C. (2018).“Poetry, Thought \& Image Interwined. El truco preferido de Satán by Walter Benjamin \& Alberto García-Alix. Comparative Studies in Modernism, n. 13, 299-310.

Eagleton, T. (2013). El acontecimiento de la literatura. Trad. Ricardo García Pérez. Barcelona: Península.

Fernández Serrato, J.C. (2015). La mirada de Orfeo: "entre" poesía e imagen en la poesía de Jenaro Talens. Valencia: Pre-Textos / Fundación Gerardo Diego.

García-Alix, A. (2008). Moriremos mirando: textos completos. Madrid: La Fábrica. 
García-Alix, A. (2011). El paraíso de los creyentes. Catálogo de la exposición. Madrid: La Oficina.

García Alix, A. y Talens, J. (2014). Lo que los ojos tienen que decir. Madrid: Cátedra.

Gómez, C. \& Sánchez-Mesa, D. (2011). La crónica de sucesos criminales en el discurso periodístico y el cinematográfico. El viaje de Edgar Neville entre la calle Fuencarral y Bordadores. Signa: Revista de la Asociación Española de Semiótica, 20, 277-304. http://revistas.uned.es/index.php/signa/article/view/6268 DOI: https://doi.org/10.5944/signa.vol20.2011

Janés, C. y Talens, J. (2013). Según la costumbre de las olas Madrid: Salto de página.

Kibédi-Varga, A. (2000). "Criterios para describir las relaciones entre palabras e imagen". En A. Monegal (Ed.) Literatura y pintura (pp.109-138). Madrid: Arco Libros, 109-138.

Mitchell, William J.T. (2019). La ciencia de la imagen. Iconología, cultural visual y estética de los medios. Madrid: Akal, Estudios Visuales.

Mitchell, William J.T. (1994) Picture Theory. Essays on Verbal and Visual Representation. Chicago: University of Chicago Press.

Monegal, A. (1998). Poesía e imagen en las vanguardias hispánicas. Barcelona: Tecnos.

Rajewsky, I. (2005). Intermediality, Intertextuality and Remediation: A Literary Perspective on Intermediality. Intermedialites/Intermedialities, $\quad 6, \quad 43-63$. http://cri.histart.umontreal.ca/cri/fr/intermedialites/p6/pdfs/p6_raj ewsky text.pdf [última consulta, 25/07/2019]

Sánchez-Mesa, D. (2007). "La mirada que escribe. Relaciones intermediales en la poesía de Jenaro Talens". En Fernández Serrato, Juan Carlos (ed.). Mi oficio es la extrañeza. Ensayos sobre la poesía de Jenaro Talens. Madrid: Biblioteca Nueva, 87-121.

Sánchez-Mesa, D. \& Baetens, J. (2017). La literatura en expansión. Intermedialidad y transmedialidad en el cruce entre la literatura comparada, los estudios culturales y los new media studies. Tropelías. Revista de Teoría de la Literatura y Literatura Comparada, 27, 6-27 https://papiro.unizar.es/ojs/index.php/tropelias/article/view/1536 (última consulta, 14/07/2017).

Talens, J. (1985). La mirada extranjera. Valencia: Fundación Instituto Shakespeare [edición no venal] (2a. ed. Madrid, Hiperión 1997), con fotografías de Michael Nerlich.

Talens, J. (1988). El sueño del origen y la muerte. Madrid: Hiperión, 1988. 
Talens, J. (1988). Five Ways to Finish August. Minneapolis: Prisma Books. Con fotografias de Christine Cotaz-Bertholet. Estudio preliminar de René Jara. Trad. de G. Colaizzi (texto bilingue).

Talens, J. (1989). Cenizas de sentido. Poesía 1962-1975. Madrid: Cátedra (1 ${ }^{\mathrm{a}}$ ed. 1975).

Talens, J. (1991). El largo aprendizaje. Poesía 1975-1991. Madrid: Cátedra.

Talens, J. (1991). Cine y (su)realismo. La concha y el reverendo frente a un perro andaluz. En El sujeto vacío. Cultura y poesía en el territorio Babel. Madrid: Cátedra, Frónesis, 2000, 149-169.

Talens, J. (1992). Moins qu'une image. Paris: Fondation Noesis. Con fotografías de Jean Paul Billerot. Trad. de D. Coste (texto bilingüe).

Talens, J. (1994). Orfeo filmado en el campo de batalla. Madrid: Hiperión.

Talens, J. (1995). De qué color son las princesas. Valencia: Episteme (ed. no venal)

Talens, J. (2000). El sujeto vacío. Poesía y cultura en territorio Babel. Madrid: Cátedra (Frónesis).

Talens, J. (2001). Profundidad de Campo. Madrid: Hiperión.

Talens, J. (2002a). Cantos rodados (Antología poética, 1960-2001). Madrid: Cátedra.

Talens, J. (2002b). "Escribir no es un sueño. Cada cosa sucede" (conversación con J.C. Fdez. Serrato, 2000). En S. Díaz (Ed.), Negociaciones. Para una poética dialógica, (pp.53-78). Madrid: Biblioteca Nueva.

Talens, J. (2002c). "Fragmentos de un diálogo radiofónico" (Conversación con Esteban Peicovich) Negociaciones. Para una poética dialógica, págs. 191-201.

Talens, J. (2015). El sueño de Einstein. Madrid: Editorial Salto de página.

Talens, J. (2015). Y se quedarán los pájaros cantando. Con fotografías de Michaël Nerlich. Cuenca: Segundo Santos Ed.

Williams, R. (1990). Television. Technology \& Cultural Form. Londres: Routledge. 